\title{
Licensing of mifepristone in New Zealand and Australia
}

The legal opinion article $^{1}$ by Sam Rowlands in the April 2012 issue of this Journal raises important issues but I would like to correct the statement regarding the licensing of mifepristone in New Zealand and Australia. The two countries have an entirely different history regarding the licensing of mifepristone. In New Zealand in 1999 a group of doctors formed a not-for-profit pharmaceutical company to import mifepristone from France. The drug was approved for use in New Zealand in 2001 and the company, Istar Ltd, has supplied Australian providers since the Australian law change in 2006.

Margaret Sparrow, FAChSHM, FRANZCOG

Istar Ltd, Wellington, New Zealand;

msparrow@value.net.nz

Competing interests The author is a Director of Istar Ltd.

J Fam Plan Reprod Health Care 2012:38:271. doi:10.1136/jpprhc-2012-100428

\section{Reference}

1 Rowlands S. Abortion pills: under whose control? J Fam Plann Reprod Health Care 2012;38:117-122. 